\title{
The Festival Internacional Cervantino in Guanajuato, Mexico: Tourist Profiles, Symbolic Anthropological Perceptions and Urban Presence
}

\author{
By Daniel Barrera-Fernández* \\ Marco Hernández-Escampa ${ }^{\dagger}$ \\ Leticia Arista Castillo
}

The Festival Internacional Cervantino is one of the leading art and culture related events in Latin America, celebrated every year in the city of Guanajuato, Mexico. The objective of the present research is to analyze the impact of this event in number and profile of visitors, as well as how its celebration affects anthropologically the symbolic perception of the city for both locals and visitors. This research is part of the ATLAS Events Monitoring Project - Comparing Event Experiences, where experts from ten countries are developing a common methodology to produce a comparative analysis in major events worldwide. In all cases, the Events Experience Survey (EES) is being applied. It consists of a 18-item scale, comprised of 4 dimensions: affective engagement, cognitive engagement, physical engagement and experiencing newness. In this case, 230 surveys that incorporated EES were applied on 7-25 October 2015, coinciding with the celebration of the $43^{\text {rd }}$ edition of the Festival Internacional Cervatino. In the case of Guanajuato, the survey has been compared to official data from the festival and completed with interviews to civil officers related to tourism management, documentary sources and direct observation. Conclusions show a gap in how the event is perceived among residents and tourists, which ultimately highlights an overconcentration of activities and an increasing difficulty in granting high quality public services during the celebration of the event. Application of EES has proved successful in terms of offering information that is not reflected in official data and contrasting them. The Festival Internacional Cervantino is one of the largest cultural events in Latin America in number of visitors and media coverage. However, it is also perceived as a meeting point for young people mostly interested in leisure activities. Application of EES reinforces this idea.

Keywords: city branding, culture, events, tourist profile, urban planning

\section{Introduction}

In recent years there have been many events held in cities and competition has risen to host those having the greatest international impact. Major events have the function to attract visitors and also serve as a marketing strategy to publicize the new image of the city to tourists, residents and investors.

\footnotetext{
*Professor and Researcher, Autonomous University of Oaxaca "Benito Juarez", Mexico.

† Professor and Researcher, Autonomous University of Oaxaca “Benito Juarez”, Mexico.

* Professor and Researcher, Autonomous University of San Luis Potosí, Mexico.
} 
Events can be defined as "a onetime or infrequently occurring event of limited duration that provides the consumer with a leisure and social opportunity beyond everyday experience" (Jago \& Shaw, 1998). Cities have always celebrated festivals, but these were created mainly for the local population, related to traditional sociocultural systems. The new reasons to celebrate festive events are now more related to improving the image of the city and attracting tourists, especially those doing short trips out of season and repeating visit. In addition, tourists visiting events spend more than average visitors (Herrero et al., 2012). Improving the image of the city will help attract investment and stimulate top executives move to live in the city. Similarly, it increases local pride and community spirit and a collective image is strengthened. In addition, events have as advantage that they can be used by cities with few attractions. In the historic city, events also have the role of bringing entertainment to attractions and spaces, helping its revitalization.

Law (1996) distinguishes three types of events: those that are part of a regular program, special events and mega events. Special events are those that are held infrequently, annually or only once. Mega-events have international scope and a large media impact, such as the Olympic Games, International Expositions, Copa America, Tall Ships' Races, etc., with them the city shows the world its organizational capacity and its power to mobilize various actors and resources, aspects valued positively by potential investors (Monclús \& Guardia, 2006). Nevertheless, the distinction between types of events is primarily psychological and each type can include international events or world famous local festivals, events lasting days or other spanning several months or even a year.

In some cases of major international events that are celebrated periodically, the brand value of the event is more powerful than the city itself. This phenomenon occurs with the European Capital of Culture, whose brand has eclipsed individual cities that are chosen as the venue. In other cases, the city's brand and the event's brand feed off each other. The case of Barcelona '92 is generally regarded as successful in this regard (Richards \& Wilson, 2007).

The extent of the benefits produced by events makes them to rival the importance of built heritage in cultural and economic strategies of cities. This is because events are more flexible than some types of physical infrastructure; they cost less and have more impact in the short term. Events also help differentiate spaces that are identical in all cities. In addition, according to Monferrer (2011), events are better able to provide entertainment and atmosphere and they meet the need for new creative participation of tourists, providing them with experiences.

In the case of mega-events, improving the image of the city occurs even since the application is presented (Giroud \& Grésillon, 2011). As a result, cities do not skimp on investing large sums of money during the selection process, regardless of subsequent costs that the city will have to face if finally chosen (Richards, 1999). The speed with which cities must act to celebrate the event hampers debate and transparency (Dredge \& Whitford, 2011). Moreover, in 
many cases the bidding effort prioritizes the interests of tourists rather than residents, resulting in the construction of attractions and infrastructure of doubtful utility. In celebration of major events the question of what to do with the facilities once the celebration is over has not had an effective answer in many cases. Examples of incomplete planning and management such as Expo '92 in Seville (Reina Fernández, 2012) and Euro 2004 in Portugal (Grande, 2012) have made other cities think twice on functional and programmatic sustainability of the investment. Another common criticism is the relationship between major events, gentrification and the design of urban spaces for consumption (Paton et al., 2012). Furthermore, the impact of singular events is limited to stimulate social interaction, being much more useful in this regard the regular cultural activities that involve citizen involvement (Askins \& Pain, 2011).

Some cities have chosen to fill the calendar with events. In order to become a city in which everything is focused on events, firstly some consistency must be achieved through a common strategy and a structure to coordinate the various programs. Given the context of the importance of creativity and intangible aspects in tourism, events become creators of meaning and image in these cases, adding a dynamic component because of their transience. In cities that choose this strategy, events dominate public life of the city (Richards \& Palmer, 2010). In the search for new events, festivals of local origin have also been reinvented to attract a larger and more diverse audience. These events serve to highlight the roots of local culture and its diversity, but if the priority is the visitors' satisfaction, events can lose their authenticity and therefore the local community's interest (Brida et al., 2013).

An example of a city that offers a calendar full of events is Edinburgh. It is estimated that in 2011 its twelve festivals were visited by more than three million people, generating 245 million pounds (295 million euros) profit and creating 5,242 full-time equivalent jobs (Del Barrio et al., 2012). The city has managed to secure a number of international tourists that repeat their visit every year. Nevertheless, a pending issue of the festival program is its inability to change the perception that tourists have of Scotland as a place of traditional landscapes and heritage (Prentice \& Anderson, 2003).

Filling the calendar with events of all kinds entails the trivialization of urban events due to the large number of cities that celebrate the same festival and the huge number of events that are held (Muñoz Ramírez, 2012). In addition, the competitive advantages are missed by sharing the benefits with a growing number of cities (Meethan \& Barrera-Fernández, 2012).

The celebration of culture is the focus of a growing number of events such as the Cultural Olympiad, Capital of Culture with its European, British and American variants, Universal Forum of Cultures, Europride, WOMEX, World Book Capital, World Design Capital, White Night, etc. In Europe, the most desired title is the European Capital of Culture, especially for cities not generally recognized as "cultural" or undergoing restructuring such as many of the cities belonging to the former Soviet bloc (Trócsányi, 2011). The main benefits associated with this title are an increase of creative tourism, the 
promotion of cultural production and consumption and the collaboration among administrations, cities and the public and private sectors in tourism management (Liu, 2012).

A particular mention should be made to the impact of festivals for urban economy. As a part of more general cultural strategies (Gotham, 2005) that involve fields such as urban studies, political economy, geography, theatre studies and event studies (Quinn, 2010); festivals have been used as a tool to regenerate redundant spaces and to develop an economy based on consumption (Zukin, 1995). Leisure, entertainment and tourism create the so-called "experience economy" (Pine \& Gilmore, 1999), where events become one of the pillars of cultural economy (Knowles, 2000). Cultural events produce enormous direct and indirect economic benefits (Gibson et al., 2009). However, it must be taken into account that the economic impact of festivals is not kept totally in the hosting city because a part of the spending goes to entities outside the local economy (Perdue et al., 1990).

Apart from their economic impact, events affect the city's social and cultural life in many ways. Social benefits and costs can be analysed through different scales and approaches (Delamere, 2001; Small, 2007; Arcodia \& Whitford, 2007; Fredline et al., 2003; Robertson et al., 2009). Small (2007) identified six dimensions of festivals' social impacts, namely inconvenience, community identity and cohesion, personal frustration, entertainment and socialization opportunities, community growth and development, and behavioral consequences. On the other hand, Gursoy et al. (2004) identified four dimensions on organizers' perceptions, namely community cohesiveness, economic benefits, social incentives and social costs. One of the major social costs is anti-social behaviour, which can seriously damage the image of the festival (Deery \& Jago, 2010), something that in fact happens to the Festival Internacional Cervantino, as it will be explained in the article.

\section{The Festival Internacional Cervantino}

The Festival Internacional Cervantino is held every Autumn in the city of Guanajuato, Mexico. It consists of more than 400 cultural and arts events including theatre, concerts, performances and exhibitions with a focus on bringing high quality international avant-garde artists. It takes place in 60 indoor venues and open air public spaces, mostly in the city centre but also in peripheral locations from the city and other surrounding municipalities. The festival is visited by more than 450,000 people every year and it has a great national media coverage, both in TV, radio and social media, with more than 150,000 followers in Facebook and Twitter (Festival Internacional Cervantino, 2015a).

The roots of the Festival Internacional Cervantino can be found in the annual representation of Miguel de Cervantes's Entremeses by Prof. Enrique Ruelas since 1953 (NOTISEM, 2013). However, the first official edition of the festival had to wait for almost two decades until 1972, when the Festival 
Internacional Cervantino was formerly held. In its foundation participated the Mexican Department of Tourism, the National Institute of Beaux Arts and the Foreign Affairs Secretariat (Guanajuato State Government, 2008). This first edition was celebrated in the Plazuela del Quijote, in Mineral de Cata, one of the mines that gave celebrity to Guanajuato thanks to the extraction of silver. The event was organized as a contribution to the Americas Tourism Year, promoted by UNESCO (Noticieros Televisa, 2012a).

In 1976 the organizing structure of the festival was settled through a federal decree. An organizing committee was established to prepare the event yearly, whose president is chosen directly by the President of the Republic. The funds for the festival were secured through federal agencies ever since. The city of Guanajuato was decided to be the centre of the festival, but the door was open to include other cities (Diario Oficial de la Federación, 1976). As a result, some events are held in surrounding municipalities. Nowadays, the three levels of government participate in the festival's organisation: the Federal Government through the National Council for Culture and Arts, the State Government through the State's Institute for Culture and the City Council. The University of Guanajuato is also part of the organizing committee (Festival Internacional Cervantino, 2015a).

As every festival, the Festival Internacional Cervantino has been subject of many transformations depending on the context. During the 1990s and first decade of the $21^{\text {st }}$ century, the Festival achieved bad reputation due to overcrowding, drunk people, insecurity and antisocial behaviour. However, in recent years the organization has increased control over drinking in the public space, there is more presence of police forces and special services have been displayed in moments of high concentration of people (Noticieros Televisa, 2012b), such as the opening, closing and concerts held in the Alhóndiga de Granaditas. In 2005, Guanajuato was declared America's Cervantes City thanks to its contribution to the knowledge and dissemination of Cervantes's works. Since 2010, a foreign country and a Mexican state are specially invited to the festival. In 2013, the social programmes Cervantino for All and A Community to the Cervantino were first established. The first one consists of the presentation of selected events in some of the less developed areas of Guanajuato State, as well as in schools, nursing homes, orphanages and hospitals. The second one brings people from remote villages to the festival, free of charge (NOTISEM, 2013). In recent years, the festival has increased its national presence through TV and radio streaming and the installation of 120 screens in different Mexican cities (Festival Internacional Cervantino, 2015b).

Apart from the official discourse about the festival, it is important to contrast information with local opinions and researchers' findings. In this regard, one of the most representative researches from an anthropological view has been carried out by Hoel (2007), which was focused on residents' perceptions, something that official data has disregarded. The perceptions of local population about the festival has also changed in time. According to this work, residents' perceptions began to change in the 1980s, when the organization started to be controlled by the Mexican Government, thus losing 
the local and State's autonomy. The programme lost its original focus on "high" culture and Cervantes and more popular commercial activities took place, which meant an increase in incomes.

Following Hoel, visitor profiles changed, with an increase of groups of young people that started to see to the festival as a rite of passage, far from the authority represented by their parents. Drugs and alcohol consumption increased dramatically, as well as antisocial behaviour and crime. As a result, local families started to feel insecure and lost presence. Most of these young people come to have fun by themselves, without taking part in the events, and as a result the festival started to be known as "the largest cantina in Mexico". Fortunately, this situation has moderated in recent years, with a higher presence of police forces and the prohibition of drinking alcohol in public spaces. However, the feeling of invasion has remained.

The colonization of young people also affects the presence of foreign tourists. Guanajuato is visited regularly by people mostly from USA and Canada, many of whom have retired in the surroundings. However, during festival days their presence is reduced significantly. In addition, the new kind of visitors attracted new businesses, which started to displace local producers, increasing the sense of invasion.

As a result of the changes mentioned, the festival has become somehow a non-place (Augé, 1992), with the kind of activities and behavioural patterns that can be found in many other events, and the original cultural atmosphere has given way to a more popular and young atmosphere.

\section{Objectives and Methodology}

The objective of the current research is to assess whether official surveys reflect the perceptions of visitors and locals when attending the Festival Internacional Cervantino. These perceptions are not considered in the public institution methodology, thus, another methodology, called Event Experience Scale (EES) has been applied in the edition 2015 and contrasted to the 2014 visitor profile official results, which are the last data that have been published.

Guanajuato State's visitor profile official results consisted of 300 surveys made in 8-26 October 2014, coinciding with the celebration of the $42^{\text {nd }}$ edition of the festival. Surveys were made to 82 locals and 218 visitors, $52 \%$ of them paid entrance to a particular event (Guanajuato State Government, 2014).

The EES consists of a 18-item scale, comprised of 4 dimensions: affective engagement, cognitive engagement, physical engagement and experiencing newness, with Cronbach's alpha values rating from .83 to .87 . This scale was presented in De Geus's doctoral thesis, under the supervision of Richards and Toepoel (Geus et al., 2015). It was applied later in different events and in 2014 an international team called ATLAS Event Experience Research Project was created to apply the scale and compare results in events from different parts of the world and of different nature. At the time of writing, ten partners were 
analysing events with the same methodology in Brazil, Bulgaria, Finland, Greece, Mexico, Netherlands, Portugal, Spain, United Kingdom and USA.

In the particular case of this research, 230 surveys that incorporated EES were applied in $7-25$ October 2015, coinciding with the celebration of the $43^{\text {rd }}$ edition of the Festival Internacional Cervatino. The questionnaire that was finally applied can be consulted in appendix 1. It was applied to 22 locals and 202 visitors. Women represented $50 \%$ of respondents, men represented $45 \%$ and $5 \%$ did not specify their gender. Surveys were made at the entrance of venues before the start of events and in the streets and public spaces joining major venues. They were applied both during working days as in weekends, since there are events scheduled all days that the festival lasts. As it can be seen, both the official and our survey was made to a similar number of respondents (300 to 230), both of them were made during all days that the festival lasts, in order to make it possible to compare data.

The methodology was as follows:

1. Adaptation of the common survey to Guanajuato's particularities: apart from the 22 questions that are applied in all cases, 8 more were added asking about use of heritage resources, tourist attractions and urban services. The questionnaire was kept in English and also translated into Spanish.

2. Surveys were made at the entrance and exit of event venues as well as in public spaces where performances took place or that were located between main venues.

3. Data was processed and contrasted to Guanajuato State's visitor profile official results.

\section{Application of EES and Key Findings}

After applying the EES, a table has been developed to show the results compared to the ones presented in Guanajuato State's visitor profile official results.

From the comparison of both methodologies, it is possible to draw a number of key findings. Our research has shown that people coming to Guanajuato having the festival as main reason are much lower than stated by official statistics. More people arrive to the city to get entertainment and to visit their friends and relatives than those who come specifically for the festival. This statement agrees to Hoel's research, who concluded that the Festival Internacionl Cervantino is mostly a meeting of young people to have fun than a traditional cultural festival as it is promoted. 
Table 1. Main Questions and Answers Applying EES Compared to Guanajuato State's Visitor Profile Official Results

\begin{tabular}{|c|c|c|}
\hline & Application of EES & Guanajuato State's visitor profile \\
\hline $\begin{array}{l}\text { What are your main reasons for } \\
\text { attending this event? }\end{array}$ & $\begin{array}{l}\text { - I like the festival }(28 \%) \\
\text { - Entertainment }(20 \%) \\
\text { - Spend time with friends and family }(20 \%)\end{array}$ & \\
\hline $\begin{array}{l}\text { Which information sources did } \\
\text { you use to plan your visit to the } \\
\text { event? }\end{array}$ & $\begin{array}{l}\text { - Family and friends: } 49 \% \\
\text { - Event website: } 31 \% \\
\text { - Previous visit: } 21 \% \\
\text { - Event brochure: } 21 \%\end{array}$ & $\begin{array}{l}\text { - Family and friends: } 18 \% \\
\text { - Event website: } 63 \% \\
\text { - Event brochure: } 8 \% \\
\text { - Signs and posters: } 12 \%\end{array}$ \\
\hline $\begin{array}{l}\text { Have you visited this event } \\
\text { before? }\end{array}$ & $\begin{array}{l}\text { - Yes: } 44 \% \text { (5 times in average) } \\
\text { - No: } 56 \%\end{array}$ & \\
\hline $\begin{array}{l}\text { Where did you stay during the } \\
\text { event? }\end{array}$ & $\begin{array}{l}\text { - At home: } 35 \% \\
\text { - Hotel: } 27 \% \\
\text { - Guest house: } 14 \% \\
\text { - With family and friends: } 21 \% \\
\text { - Other: } 3 \%\end{array}$ & $\begin{array}{l}\text { - Hotel: } 41 \% \\
\text { - Guest house: } 11 \% \\
\text { - With family/friends: } 20 \% \\
\text { - Other locality: } 24 \% \\
\text { - Rented house: } 4 \%\end{array}$ \\
\hline $\begin{array}{l}\text { How likely are you to visit this } \\
\text { event in the future? }\end{array}$ & $8.56 / 10$ & $96 \%$ definitively or probably yes \\
\hline $\begin{array}{l}\text { How likely are you to } \\
\text { recommend this event to } \\
\text { family/friends? }\end{array}$ & $8.56 / 10$ & $97 \%$ definitively or probably yes \\
\hline $\begin{array}{l}\text { How important was this event } \\
\text { in your decision to visit } \\
\text { Guanajuato today? }\end{array}$ & $\begin{array}{l}\text { - Only reason: } 25 \% \\
\text { - One of the main reasons: } 25 \% \\
\text { - One of several reasons: } 28 \% \\
\text { - Not a factor: } 22 \%\end{array}$ & $\begin{array}{l}\text { - Main reason: } 88 \% \\
\text { - Not main reason: } 12 \% \\
\text {. Holidays: } 50 \% \\
\text {. Visit friends/family: } 31 \%\end{array}$ \\
\hline
\end{tabular}




\begin{tabular}{|c|c|c|}
\hline $\begin{array}{l}\text { What would you probably be } \\
\text { doing today if the event was not } \\
\text { being held? }\end{array}$ & $\begin{array}{l}\text { - Stayed at home/gone to work: } 41 \% \\
\text { - Done something else in Guanajuato: } 32 \% \\
\text { - Visited another destinations: } 14 \% \\
\text { - Visited another part of the region: } 9 \% \\
\text { - Gone somewhere outside the region: } 4 \%\end{array}$ & \\
\hline Average spending & $\begin{array}{l}147 € \\
\text { - Mexicans: } 64 € \\
\text { - Foreigners: } 658 €\end{array}$ & \\
\hline Origin & $\begin{array}{l}\text { - Mexico: } 87 \% \\
\text {. Guanajuato: } 55 \% \\
\text { + Guanajuato City: } 28 \% \\
\text { + Irapuato: } 14 \% \\
\text { + Uriangato: } 14 \% \\
\text { + Celaya: } 9 \% \\
\text { + León: } 6 \% \\
\text { + Other: } 29 \% \\
\text {. Mexico City: } 13 \% \\
\text {. State of Mexico: } 8 \% \\
\text {. Other: } 24 \% \\
\text { - USA: } 11 \% \\
\text { - Other country: } 2 \%\end{array}$ & $\begin{array}{l}\text { - Local: } 33 \% \\
\text { - Visitor: } 67 \% \\
\text {. Mexico: } 96 \% \\
\text { + Guanajuato: } 21 \% \\
\text { *León: } 54 \% \\
\text { *Irapuato: } 14 \% \\
\text { *Other: } 32 \% \\
\text { + Other state: } 75 \% \\
\text { * Mexico City: } 33 \% \\
\text { * St. of Mexico: } 15 \% \\
\text { * Other: 52\% } \\
\text {. Abroad: } 4 \% \\
\text { + USA: } 78 \% \\
\text { + Other country: } 22 \%\end{array}$ \\
\hline
\end{tabular}




\begin{tabular}{|c|c|c|}
\hline Composition of group & $\begin{array}{l}\text { - } 4 \text { adults in average } \\
\text { - } 2 \text { children in average } \\
\text { - Alone: } 24 \% \\
\text { - Accompanied: } 76 \%\end{array}$ & $\begin{array}{l}\text { - } 3 \text { adults in average } \\
\text { - Alone: } 12 \% \\
\text { - Accompanied: } 88 \% \\
\text {. With friends: } 31 \% \\
\text {. In couple: } 29 \% \\
\text {. With the family: } 26 \% \\
\text {. Other: } 14 \%\end{array}$ \\
\hline Gender & $\begin{array}{l}\text { - Female: } 50 \% \\
\text { - Male: } 45 \% \\
\text { - Other/did not answer: } 5 \%\end{array}$ & $\begin{array}{l}\text { - Female: } 52 \% \\
\text { - Male: } 48 \%\end{array}$ \\
\hline Age group & $\begin{array}{l}-15 \text { or less: } 3 \% \\
-16-19: 14 \% \\
-20-29: 60 \% \\
-30-39: 17 \% \\
-40-49: 5 \% \\
-50-59: 1 \% \\
-60 \text { or over: } 0 \%\end{array}$ & $\begin{array}{l}-18-19: 4 \% \\
-20-29: 46 \% \\
-30-39: 20 \% \\
-40-49: 10 \% \\
-50-59: 11 \% \\
-60 \text { or over: } 9 \%\end{array}$ \\
\hline Highest level of qualification & $\begin{array}{l}\text { - Primary: } 1 \% \\
\text { - Secondary: } 1 \% \\
\text { - Further education: } 20 \% \\
\text { - Higher education: } 71 \% \\
\text { - Postgraduate: } 7 \%\end{array}$ & \\
\hline Kind of job & $\begin{array}{l}\text { - Student: } 51 \% \\
\text { - Academic profession: } 30 \% \\
\text { - Other: } 19 \%\end{array}$ & \\
\hline
\end{tabular}




\begin{tabular}{|c|c|c|}
\hline Average gross income per year & $7,500 €$ & \\
\hline $\begin{array}{l}\text { Did you share any information } \\
\text { about this event via social } \\
\text { media? }\end{array}$ & $\begin{array}{l}\text { - Yes, before the event: } 31 \% \\
\text { - Yes, during the event: } 43 \% \\
\text { - Yes, after the event: } 10 \% \\
\text { - No: } 69 \%\end{array}$ & \\
\hline $\begin{array}{l}\text { Which social media did you } \\
\text { use? }\end{array}$ & $\begin{array}{l}\text { - Facebook: } 49 \% \\
\text { - Twitter: } 30 \% \\
\text { - Snapchat: } 13 \% \\
\text { - Other: } 8 \%\end{array}$ & \\
\hline $\begin{array}{l}\text { In what activities did you take } \\
\text { part? }\end{array}$ & $\begin{array}{l}\text { - Attending cultural events: } 77 \% \\
\text { - Bars/night clubs: } 60 \% \\
\text { - Restaurants: } 52 \% \\
\text { - Shopping: } 31 \%\end{array}$ & \\
\hline Aspects valued more positively & $\begin{array}{l}\text { - Quality of events } \\
\text { - Leisure offer }\end{array}$ & $\begin{array}{l}\text { - Quality of events } \\
\text { - Number of attendants per event } \\
\text { - Help provided by organizers }\end{array}$ \\
\hline Aspects valued more negatively & $\begin{array}{l}\text { - Accessibility } \\
\text { - Language skills of the service providers } \\
\text { - Traffic } \\
\text { - Parking }\end{array}$ & $\begin{array}{l}\text { - Low level of skills } \\
\text { - Traffic } \\
\text { - Overcrowded } \\
\text { - Lack of public toilets }\end{array}$ \\
\hline
\end{tabular}




\begin{tabular}{|c|c|c|}
\hline Visit to other destinations & $\begin{array}{l}\text { - San Miguel: } 37 \% \\
\text { - Cubilete: } 19 \% \\
\text { - Dolores Hidalgo: } 23 \% \\
\text { - Other: } 21 \%\end{array}$ & $\begin{array}{l}\text { - No: } 68 \% \\
\text { - Yes: } 32 \% \\
\text { Most popular: León, San Miguel, Dolores Hidalgo, } \\
\text { Silao, Irapuato }\end{array}$ \\
\hline Kind of transport in the city & $\begin{array}{l}\text { - Only walking: } 45 \% \\
\text { - Walking + tour bus: } 10 \% \\
\text { - Walking and taxi: } 19 \% \\
\text { - Walking and regular bus: } 31 \%\end{array}$ & $\begin{array}{l}\text { - Bus: } 43 \% \\
\text { - Own car: } 25 \% \\
\text { - Rented car: } 13 \% \\
\text { - Taxi: } 19 \%\end{array}$ \\
\hline Events attended & $\begin{array}{l}\text { - Teatro Juárez: } 14 \% \\
\text { - Closing ceremony: } 11 \% \\
\text { - Alhóndiga: } 16 \% \\
\text { - Open air in Pastitos: } 8 \%\end{array}$ & $\begin{array}{l}\text { - Music: } 83 \% \\
\text { - Street performances: } 68 \% \\
\text { - Theatre: } 54 \% \\
\text { - Dance: } 51 \%\end{array}$ \\
\hline
\end{tabular}

Source: the authors 
Another major difference in results between both methodologies is in relation to sources of information. Our research has revealed that most people gather information from friends, relatives and previous visitors, rather than websites or marketing campaigns, which is in line with the fact that most people come to have fun and stay with their family and friends in the city. Furthermore, there is a huge difference in spending between foreigners and Mexicans (10 to 1), which suggests that most Mexicans are students, something that is demonstrated when asked about profession and age group. In these two topics, there is also a great gap between our results and official ones, showing a larger number of young students than expected.

Going to bars and restaurants is the most recurrent activity after attending cultural events and, regarding place to stay, data reveal that most people stay at their own home or with family and friends, which reinforces the previous statement. Informal accommodation is a particular feature from this festival and one of the main problems, since there is a relevant offer of shared rooms even without showers and bathrooms, which is one of the causes of residue accumulation in the alleys. In fact, lack of public toilets is one of the strongest demands registered in official data. Another one of the worst valued aspects is accessibility for people with disabilities, which did not appear in official data and is one of the major problems in Guanajuato's urban spaces, since, as data show, most people walk the streets instead of using any method of public or private transport.

Our study has shown that not so many people are likely to visit the event again or recommend it as official data say, indicating that may be the latter are overoptimistic. In relation to origin, both methodologies arrive to the same conclusion of the low presence of foreigners.

\section{Conclusions}

The Festival Internacional Cervantino is one of the largest cultural event in Latin America in terms of the number of visitors and media coverage. However, it is also perceived as a meeting point for young people mostly interested in leisure activities. Application of EES reinforces this idea, previously stated by Hoel (2007) which is only partially shown in official data. Taking this fact into account, it might make authorities consider some key aspects in order to improve the image and management of the festival as well as to enhance the festival experience. From an anthropological point of view, the former historic emphasis of this event on cultural activities should be highlighted in order to avoid the perception of a just leisure moment. This is coherent with the generalized perception of the urban environment as historic and traditional. In urban management terms, residues presence is one of the major problems in terms of perception, which needs a strong response. Since most people walk the streets during festival days, strategies to improve accessibility, design for all and public transport are crucial. Stronger controls 
over undeclared, informal and substandard accommodation should be a priority to change the visitors' profile, focusing on higher income groups.

Application of EES has proved successful in terms of offering information that is not reflected in official data and contrasting them. Some of the questions answered thanks to EES - they would have remained unanswered otherwise are the number of previous visits, what people would have done if the event was not held, personal spending, detailed use of social networks and activities undertaken while in the city. In addition, some questions have been given more answers, which have allowed arriving to different conclusions than the ones extracted from official data such as previous visits as a source of information, allowing an open answer in the question about gender and introducing walking as a way of moving in the city.

EES is a methodology that has been designed to establish comparative studies in events organized in different countries. Nevertheless, improvements and adaptations need to be made in each case. In the case of Mexico, it is suggested to include in the survey one of the most used social media: WhatsApp. In addition, it is suggested to specifically ask for monthly income instead of yearly income, something that local people are not used to be asked for. These both features should be incorporated in future applications of EES.

\section{References}

Arcodia, C. and Whitford, M. 2007. Festival attendance and the development of social capital. Journal of Convention \& Event Tourism, 8, 2, 1-18.

Askins, K., and Pain, R. 2011. Contact zones: participation, materiality, and the messiness of interaction. Environment and Planning D: Society and Space, 29, 803-821.

Augé, M. 1992. Los no lugares. Espacios del anonimato. Una antropología de la sobremodernidad. Gedisa, Barcelona.

Bernad Monferrer, E. Eventos y ciudad: los eventos como elementos clave para la proyección territorial. Revista de Comunicación y Nuevas Tecnologías. Actas ICONO $14-n^{o}$ 8. II Congreso de Ciudades Creativas (Madrid, October 26-28, 2011).

Brida, J. G., Disegna, M., and Osti, L. 2013. Perceptions of authenticity of cultural events: a host-tourist analysis. Tourism, Culture \& Communication, 12, 85-96.

Deery, M. and Jago, L. 2010. Social impacts of events and the role of anti-social behaviour. International Journal of Event and Festival Management, 1, 1, 8-28.

Del Barrio, M. J., Devesa, M., and Herrero, L. C. 2012. Evaluating intangible cultural heritage: The case of cultural festivals. City, Culture and Society, 3, 235-244.

Delamere, T. A. 2001. Development of a Scale to Measure Resident Attitudes Toward the Social Impacts of Community Festivals, Part II. Verification of the Scale. Event Management, 7, 1, 25-38.

Diario Oficial de la Federación 16/03/1976. Decreto por el que se crea el Comité Organizador del Festival Internacional Cervantino, cuyo objeto será la organización del citado evento.

Dredge, D., and Whitford, M. 2011. Event tourism governance and the public sphere. Journal of Sustainable Tourism, 19, 4-5, 479-499. 
Festival Internacional Cervantino. 2015a. Festival Internacional Cervantino ¿Un ejemplo a seguir?

Festival Internacional Cervantino. 2015b. Presentación XLIII Festival Internacional Cervantino.

Fredline, L., Jago, L. and Deery, M. 2003. The development of a generic scale to measure the social impacts of events. Event Management, 8, 1, 23-37.

Geus, S. D., Richards, G., and Toepoel, V. 2015. Conceptualisation and operationalisation of event and festival experiences: Creation of an event experience scale. Scandinavian Journal of Hospitality and Tourism, 16, 3, 274296.

Gibson, C., Waitt, G., Walmsley, J. and Connell, J. 2009. Cultural festivals and economic development in nonmetropolitan Australia. Journal of Planning Education and Research.

Giroud, M., and Grésillon, B. 2011. Devenir capitale européenne de la culture: principes, enjeux et nouvelle donne concurrentielle. Cahiers de Géographie du Québec, 55, 155, 237-253.

Gotham, K. F. 2005. Theorizing urban spectacles. City, 9, 2, 225-246.

Grande, N. Portugal eventual: de Lisboa'94 a la Eurocopa 2004. Legado de un Decenio de grandes eventos urbanos. In Seminario Internacional sobre Eventos Mundiales y Cambio Urbano (Seville, November 26-28, 2012).

Guanajuato State Government. 2008. Resultados del Festival Internacional Cervantino 2008.

Guanajuato State Government. 2014. Festival Internacional Cervantino 2014. Perfil del Visitante.

Gursoy, D., Kim, K. and Uysal, M. 2004. Perceived impacts of festivals and special events by organizers: an extension and validation. Tourism Management, 25, 2, 171-181.

Herrero, L. C., Sanz, J. A., Bedate, A., and Del Barrio, M. J. 2012. Who pays more for a cultural festival, tourists or locals? A certainty analysis of a contingent valuation application. International Journal of Tourism Research, 14, 495-512.

Hoel, E. N. 2007. Transformaciones y efectos socio-culturales del Festival Internacional Cervantino en la ciudad de Guanajuato a finales del siglo XX. Master Thesis. Universidad Autónoma de Querétaro.

Jago, L. K., and Shaw, R. N. 1998. Special events: A conceptual and definitional framework. Festival Management and Event Tourism, 5, 1, 21-32.

Knowles, R. 2000. Making meaning in the late-capitalist cultural economy of the International Theatre Festival. Gestos: teoría y práctica del teatro hispánico, 29, 39-55.

Law, C. M. 1996. Urban tourism. Attracting visitors to large cities. Mansell Publishing Limited, London and New York.

Liu, Y. 2012. Cultural events and cultural tourism development: lessons from the European Capitals of Culture. European Planning Studies, 22, 3, 498-514.

Meethan, K., and Barrera-Fernández, D. 2012. Urban transformations from being designated European Capital of Culture. In Seminario Internacional sobre Eventos Mundiales y Cambio Urbano (Seville, November 26-28, 2012).

Monclús, J., and Guardia, M. (eds.). 2006. Culture, urbanism and planning. Ashgate, Aldershot.

Muñoz Ramírez, F. 2012. Los megaeventos en la ciudad del siglo XXI: cuatro hipótesis para el futuro del acontecimiento urbano. Seminario Internacional sobre Eventos Mundiales y Cambio Urbano (Seville, November 26-28, 2012). 
Noticieros Televisa. 2012a. Festival Internacional Cervantino, 40 años de historia. October 3, 2012. Retrieved from: http://noticierostelevisa.esmas.com/especiales/ 507831/festival-internacional-cervantino-40-anos-historia/

Noticieros Televisa. 2012b. Los entretelones del Festival Internacional Cervantino. October 2, 2012. Retrieved from: http://noticierostelevisa.esmas.com/especiales/ 507328/los-entretelones-del-festival-internacional-cervantino/

NOTISEM. 2013. Edición del Festival Internacional Cervantino de Guanajuato.

Paton, K., Mooney, G., and McKee, K. 2012. Class, citizenship and regeneration: Glasgow and the Commonwealth Games 2014. Antipode, 44, 1, 470-1.489.

Perdue, R. R., Long, P. T. and Allen, L. 1990. Resident support for tourism development. Annals of tourism Research, 17, 4, 586-599.

Pine, B. J. and Gilmore, J. H. 1999. The experience economy: work is theatre \& every business a stage. Harvard Business Press.

Prentice, R., and Andersen, V. 2003. Festival as creative destination. Annals of Tourism Research, 30, 1, 7-30.

Quinn, B. 2010. Arts festivals, urban tourism and cultural policy. Journal of Policy Research in Tourism, Leisure \& Events, 2, 3, 264-279.

Reina Fernández, J. C. 2012. Eventos mundiales: teatro versus realidad. La relevancia de los espacios públicos urbanos. In Seminario Internacional sobre Eventos Mundiales y Cambio Urbano (Seville, November 26-28, 2012).

Richards, G. 1999. The European cultural capital event: strategic weapon in the cultural arms race?. Journal of Cultural Policy, 6, 2, 159-181.

Richards, G., and Palmer, R. 2010. Eventful cities. Cultural management and urban revitalization. Elsevier.

Richards, G., and Wilson, J. 2007. Creativities in tourism development. In G. Richards, and J. Wilson (eds.). Tourism, creativity and development. Routledge, London.

Robertson, M., Rogers, P. and Leask, A. 2009. Progressing socio-cultural impact evaluation for festivals. Journal of Policy Research in Tourism, Leisure and Events, 1, 2, 156-169.

Small, K. 2007. Social dimensions of community festivals: An application of factor analysis in the development of the Social Impact Perception (SIP) scale. Event Management, 11, 1-2, 45-55.

Trócsányi, A. 2011. The spatial implications of urban renewal carried out by the ECC programs in Pécs. Hungarian Geographical Bulletin, 60, 3, 261-284.

Zukin, S. 1995. The cultures of cities. Blackwell, Oxford. 


\section{Appendix}

Questionnaire applying EES methodology in the Festival Internacional Cervantino

\section{Events Experience Survey}

Do vou have 5 minules to spare? Tell the coganizers wast yrou thirk of this covent We are investionting the sooat cultural and economic impact of the festival. Thanks for your fimel

1. What are your main reasons for attending this event? (Floose sevect any that opply)

$\square$ I like the festival $\square$ The prodramme

Entertainment

Spend time with friends ffamily

Special cocesion

Other please state

To learn scmething

Toty simething new

To see a specific pertormer

. Which information sources did you use to plan your visit to the event? (Please solect any that appin)

口 Previous visit

$\square$ Family. friends

TViradio

Tourist office

Event webeite

Other webste

$\square$ Event brochiure

Newspaperimagazine

Tour operator brochure

$\square$ Guide bock

Social media

Other

3. Have you visited this event before? (Ploase select ono)

O Yes

$O$ No

If yes, how many times?

4. Where did you stay during the event? (Ploase seloct one)

O At home

O Hotel $\quad$ O Campshe

O AirBri B O Guest Houso Bedk Brealfast

Other, plesse specity

5. How likely are you to visit this event again in the future? (Flosse crecle a number from 1 to 10)

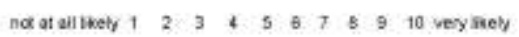

6. How likely are you to recommend this event to familyifriends? (Plesse crcie a number from 1 bo 10)

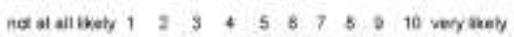

7. How important was this event in your decision to visit (destination) today? (Please select one)

Only reason for visiting this destination

One of the main reseons for visiting this destination

O One of several reasons for visting this destination

O Not a factor, would have visited anyway (e g on holday here, or visting friendafaming

8. What would you probably be doing today if the event was not being held? jplease solect one

O I would have stayed at home / gone to work

I would have done something eise in this destination

O I would have visted another destinations. nearty

O I would have visted another part of the repon

0 I wouid have gone somewhere outside this region
9. Please score the following statements on a scale from 1 (totally disagree) to 7 (totally agree) $\mathrm{N}=$ Don't Know

\begin{tabular}{|c|c|c|}
\hline & & \\
\hline Toas exthed & वodo & 0000 \\
\hline 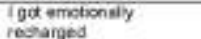 & oo & \\
\hline Tesperionod intmosy & वंōo & 000 \\
\hline 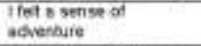 & $000 \mathrm{C}$ & 000 \\
\hline $\begin{array}{l}\text { I was wware of my own } \\
\text { volues }\end{array}$ & dodo & 000 \\
\hline 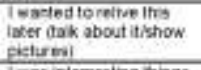 & doc & 000 \\
\hline $\begin{array}{l}\text { Teas interpreting tings } \\
\text { sor moset }\end{array}$ & dodo & Oc \\
\hline Twas ghirwing & 0000 & odo \\
\hline Tuseti my hitesad & & \\
\hline ilearned sochething & odo & \\
\hline $\begin{array}{l}\text { Tacpoured neN } \\
\text { knowledpe }\end{array}$ & 000 & \\
\hline 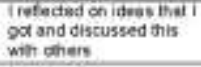 & 0 & \\
\hline I was octive & go & \\
\hline $\begin{array}{l}\text { Idid nd wet } \\
\text { particp ote }\end{array}$ & ood & $\alpha 00$ \\
\hline Teas not beng sre: & वेoo & 000 \\
\hline $\begin{array}{l}\text { Tis exent was offerent } \\
\text { tom athers }\end{array}$ & 0000 & 000 \\
\hline $\begin{array}{l}\text { TFas outside mo hames } \\
\text { life: }\end{array}$ & 0000 & O \\
\hline Thanget ins w & & \\
\hline
\end{tabular}

10. Can you indicate your average spending per person during the whole event?

$$
\text { Total }
$$

11. Where do you live?

$O$ in this ocuntry (olease give postcode)

O Abroad, (country)

$$
\text { (citytegion) }
$$

12. How many people were there in your party. including yourself? (please indicate number)

13. Are you. Aduts $\square$ Children

O Male

O Female

14. Please indicate your age group?

O 15 or younger $O 40-49$

O $16-19 \quad 0$ 50-59

O $20-29 \quad 0$ or over

30.39

15. What is you highest level of educational qualification? (please select one)

O Primary school

O secondary schoo

O Further education

Higher education (first degree:

Postgraduate 
16. Indicate your current (or former) occupational group (ovesse select ane)

O Director or manager

O Academic professions (doctor, lawyer, etc.)

O Technical professions (technicians, nursing)

O Clericaladministration

O Service and sales personnel

O Manual or crafts worker

O student

17. Which category best describes your annual household gross income? (pisase select one)

$\mathrm{O}<5,000$ dollar O $30,001-40,000$ dollar

O 5, 001 - 10,000 dollar

O $10,001-20,000$ dollar

O 20,001 - 30,000 dollar

$40,001-50,000$ dollar

O $50,001-60,000$ dollar

O $>60,000$ dollar

18. Did you share any information about this event via social media?

$\square \quad$ Yes, before the event
Yes, during the event
$\square \quad$ Yes, after the event

므№

19. If you shared information, which social media did you use? (Please seloct any that apply)

口 Facebook

$\square$ Snapchat

$\square$ instagram

Linkedin

Twitter

Other, please specif

Youtube 20. Where did you stay during the festival?
Guanajuato how many nights?

Guanajuato

Other places how many nights?

21. To which events you have attended or plan to attend?

22. Which adjectives define in a better way Guanajuato City?

$\square$ Colonial

Modern
Cosmopolitan

$\square$ Traditional

Out-of-date

Plural and diverse

Historic

23. What kinds of transport do you use in the city?

Waking $\square$ Waking \& Tax

$\square$ Walking \& Tour bus $\square$ Walleng \& Bus

24. In what activities have you taken part during the celebration of the festival?

$\square$ Astending cultural events

Restaurants

Outdoor activities

Others

$\square$ Shopping

맘Ninht clubs

Visit to

surfounding cries
25. Please score the following aspects on a scale from 1 (totally disagree) to 5 (totally agree):

\begin{tabular}{|c|c|c|c|c|}
\hline & 1 & 2 & 3 & 4 \\
\hline Schectule of merts & 0 & 0 & 0 & 0 \\
\hline Cost of everts & 0 & 0 & 0 & 0 \\
\hline Ouaing of everts & 0 & 0 & 0 & \\
\hline Dreesily of events & 0 & 0 & 0 & 0 \\
\hline Ditusion of eventes & 0 & 0 & 0 & 0 \\
\hline Venues $\alpha$ erents & 0 & 0 & 0 & \\
\hline Steet deaning & 0 & 0 & 0 & \\
\hline Public transportation & 0 & 0 & 0 & 0 \\
\hline Tour guides & 0 & 0 & 0 & 0 \\
\hline Tourist information & 0 & 0 & 0 & \\
\hline Oually of ar and waber & 0 & 0 & 0 & \\
\hline Noise & 0 & 0 & 0 & \\
\hline Heritege conservation & 0 & 0 & 0 & \\
\hline Heath care & 0 & 0 & 0 & \\
\hline Signage & 0 & 0 & 0 & \\
\hline Beconity & 0 & 0 & 0 & \\
\hline Letibuie and fin activies & 0 & 0 & 0 & \\
\hline Senvice and hoeskality & 0 & 0 & 0 & 0 \\
\hline Value for money & 0 & 0 & 0 & 0 \\
\hline Lodging & 0 & 0 & 0 & \\
\hline Gastronomic other & 0 & 0 & 0 & 0 \\
\hline Acressibiliy for disobled peocle & 0 & 0 & 0 & \\
\hline $\begin{array}{l}\text { Languape skls of the senvise } \\
\text { prowders }\end{array}$ & O & O & 0 & $\mathrm{O}$ \\
\hline Trafict & 0 & 0 & 0 & \\
\hline & & & & \\
\hline
\end{tabular}

26. In Guanajuato's downtown during your stay you have visited.

$\square$ Basilica

Belen Church Mercado Hidalgo

San Roque Church $\square$ Diego Rivera Museum

People's Museum Guanajuato University

Museo Iconográdico del Quijote

Others

27. A part from Guanajuato's downtown, during your stay you have visited.

$\square$ Valenciana $\quad$ Plaza Pozuelos

Museo de las Momias D Presa de la Olla

Pipila monument $\square$ Paseo de la Press

$\square$ Others

28. Apart from Guanajuato City, during your stay you have visited.

Mneral de Pozos

$\square$ El Cubilete

Dolores Hidalpo

Others

29. Observations/Comments

30. Thank you for participatingl If you would like to help us further by giving us more information about your experience at this event lave your about your experience

Email address

Source: the authors. 